\title{
KECURANGAN LAPORAN KEUANGAN DALAM PERSPEKTIF FRAUD TRIANGLE
}

\author{
Indira Shinta Dewi, SE., MM., Ak \\ indiradewi20@gmail.com
}

Universitas Satya Negara Indonesia

\begin{abstract}
ABSTRAK
Memperoleh bukti empiris bagaimana pengaruh kecurangan laporan keuangan dalam persepektif fraud tringle menggunakan model Beneish, merupakan tujuan dari penelitian ini. Variabel penelitian berupa segitiga penipuan yaitu indicator Tekanan, Peluang, dan Rasionalisasi, diukur dengan proksi masing-masing

Bursa Efek Indonesia dengan sector manufaktur tahun 2018-2020 menjadi sampel penelitian. Sampel penilitian sebanyak 88 laporan keuangan dengan metode penarikan sample secara purposive sampling. Regresi logistik sebagai analisis data . Hasil penelitian hanya variable Nature of Industry yang mempunyai pengaruh terhadap kecurangan laporan keuangan. Organizational Structure,Ineffective Monitoring.Organizational Structure, Ineffective Monitoring, Rationalization tidak berpengaruh terhadap kecurangan laporan keuangan.
\end{abstract}

Kata kunci : Kecurangan laporan keuangan, Fraud Triangle, Beneish Model

\section{PENDAHULUAN}

Kecurangan dilakukan dengan berbagai motivasi akibat adanya kepentingan antara manajemen (Agent) dengan investor (Principal) yang berbeda akibatnya manajemen terrdorong melakukan manipulasi keuangan. Perbedaan kepentingan principal dengan agen dapat mengakibatkan konflik keagenan di perusahaan. Principal menginginkan pihak agen untuk melakukan sesuatu yang berhubungan dengan kebutuhan principal seperti memberikan return yang besar untuk para investor perusahaan. Sementara itu agen juga ingin memaksimalkan kesejahteraan agen. Perbedaan kepentingan itu menimbulkan asimetri informasi akibatnya dapat menimbulkan risiko kecurangan. Financial statement fraud merupakan bentuk pelanggaran etika dalam berbisnis.

Berdasarkan survey ACFE tahun 2016-2020 menunjukkan bahwa fraud laporan keuangan selalu terjadi setiap tahunnya. Tahun 2016 presentase terkecil adalah fraud laporan keuangan sebesar 4\% namun kerugian yang ditimbulkan cukup besar diatas 10 Milyar rupiah. Tahun 2019 menunjukkan hasil bahwa korupsi (64,4\%) adalah kecurangan yang seringa ada di Indonesia . fraud selanjutnya penyalahgunaan asset/kekayaan negara dan perusahaan (28.9\%), fraud laporan keuangan sebesar 6,7\%.

Profesor Budi Kagramanto seporang pakar hukum bisnis di Universitas Airlangga (beritasatu.com) menilai kegiatan memanipulasi laporan keuangan menjadi cantik dimata investor diakhir periode sering disebut window dressing . salah satu

Jurnal Ilmiah Akuntansi dan Ekonomi Volume. 6 Nomor. 2, Agustus 2021 Hal. 16 
laporan keuangan,PT Tiga Pilar Sejahtera Food Tbk (AISA) adalah contoh kasus tahun 2017 yang dilakukan oleh manajemen dengan memanipulasi laporan keuangan. AISA. Tindakan manipulasi ini akan merugikan banyak pihak, pihak investor, perusahaan itu sendiri dan merusak citra pasar modal.

Kecurangan pada laporan keuangan yang adalah tindakan memanipulasi isi laporan keuangan bertujuan memperoleh keuntungan sepihak. Kecurangan yang dilakukan adalah salah satu bentuk tindakan melanggar prinsip akuntansi yang harus diungkapkan semuanya dan tidak ada yang disembunyikan.

Donald R Cressey (1953) mengamati penyebab terjadinya kecurangan hingga sekarang masih digunakan peneliti sebagai pendekatan untuk mendeteksi suatu tindak kecurangan laporan keuangan. Dikatakan fraud triangle sebab ada tiga tahap penting penyebab terjadinya kecurangan. yaitu pressure, opportunity, dan razionalitation.

Menganalisis laporan keuangan yang mengalami kecurangan dapat dilakukan dengan beberapa alat ukur pendeteksian kecurangan salah satunya menggunakan delapan indeks rasio kunci Beneish.

Perusahaan manufaktur memiliki akun persediaan dan akun yang tidak dapat tertagih yang tinggi, kemungkinan kecurangan banyak terjadi di sector ini sehingga penelitian ini menggunakan sector manufaktur sebagai objek penelitian yang dilakukan. Pemilihan sector ini didukung dengan teori yang yang dijelaskan oleh Summers dan Sweeney (1998) mencatat estimasi dari persediaan, akun yang tidak dapat ditagih yang ditentukan secara subyektif. Auditor dapat Fokus di akun tersebut saat perusahaan memanipulasi laporan keuangan.

\section{LANDASAN TEORI \\ Fraud}

Committee of Sponsoring Organizations of the Threadway Commission atau COSO (2016), fraud merupakan sesuatu yang dilakukan dengan sengaja atau kelalaian yang dibuat guna melakukan kecurangan yang dapat merugikan orang lain, sehingga korbannya mengalami kerugian dan atau pelaku memperoleh keuntungan pribadi.

Association of Certified Fraud Examiners atau ACFE (2016) mengkategorikan Fraud sebagai Penyalahgunaan Aset ,Kecurangan Laporan keuangan, Korupsi

Beneish (1999) menemukan model untuk mendeteksi terjadinya manipulasi laba di laporan keuangan dengan memakai delapan indeks rasio kunci. Indeks rasio kunci yaitu: (1) Gross Margin Index; (2) Days Sales Receivables Index; (3) Sales Growth Inde x(4) Total Accrual to Total Assets Index (5) Asset Quality Index; (6) Depreciaton Index; (7) Leverage Index; (8) Sales, General, and Administrative Expense

\section{Fraud Triangle \\ Pressure}

Fraud dapat terjadi jika seseorang mendapat tekanan seperti gaya hidup yang mewah, adanya hutang atau tagihan yang menumpuk,

\section{Financial Stability}

Financial Stability, kondisi yang memaksa perusahaan membuat keadaan keuangan menjadi stabil. Perusahaan akan memanipulasi laba pada saat kondisi 
keuangan perusahaan tidak stabil atau profitabilitasnya terancam oleh industry persaingan yang ketat, kondisi ekonomi, penurunan permintaan, dan pertumbuhan yang sangat tinggi atau profitabilitas yang tidak biasa.

Skousen et al. (2009) memproksikan Financial Stability dengan perubaahn total asset.

$$
\text { ACHANGE = \%Perubahan aset selama dua tahun }
$$

Jika persentase perubahan aset mengalami kenaikan yang relevan maka dapat dikatakan bahwa kondisi keuangantersebut dapat dikatakan stabil.

\section{External Pressure Personal}

Skousen et al. (2009) External Pressure merupakan keadaan dimana perusahaan mampu membayar hutang memenuhi persyaratan daftar - tukar, atau mampu untuk memperoleh hutang. Manajer dapat tekanan karena kebutuhan perusahaan memperoleh tambahan utang atau pembiayaan ekuitas. Maka untuk mengukur external pressure dapat menggunakan ratio leverage.

\section{Financial Target}

Chyntia (2016) berpendapat bahwa target keuangan merupakan tercapainya suatu laba atas semua usaha yang dilakukan untuk mencapi sesuatu. Target ini dibebankan ke manajer dan pegawai untuk dapat memperoleh laba setinggi-tingginya. Return on asset atau ROA sebagai indicator dari Financial Target

\section{Opportunity}

Widiarti 2015, Opportunity merupakan peluang yang dapat menimbulkan fraud. Lemahnya pengendalian internal, lemahnya pengawasan manajemen atau salah penggunaan posisi wewenang menjadi penyebab terjadinya fraud.

\section{Nature of Industry}

La Porta et al. (1999) dalam widiyanto, sebelum perusahaan-perusahaan di Indonesia mempublish laporan keuangannya lebih dahulu mempersiapkan anak perusahaan yang nantinya membeli saham perusahaan induk. Jika dirasa cukup besar transaksi Bersama pihak yang memiliki ikatan istimewa dengan perusahaan kemungkinan ada praktek manajemen laba

Nature of Industry di proksikan dengan Transaksi hubungan istimewa dihitung dengan menggunakan rumus :

$$
R P T=\frac{\text { total seluruh piutang istimewa }}{\text { total piutang seluruh perusahaan }}
$$

\section{Rationalization (rasionalisasi)}

Pergantian auditor adalah usaha yang dilakukan perusahaan untuk menghindari kecurangan.

AUDCHANGE = (1) melakukan perubahan auditor dalam 2 tahun,

(0) tidak melakukan perubahan auditor. 


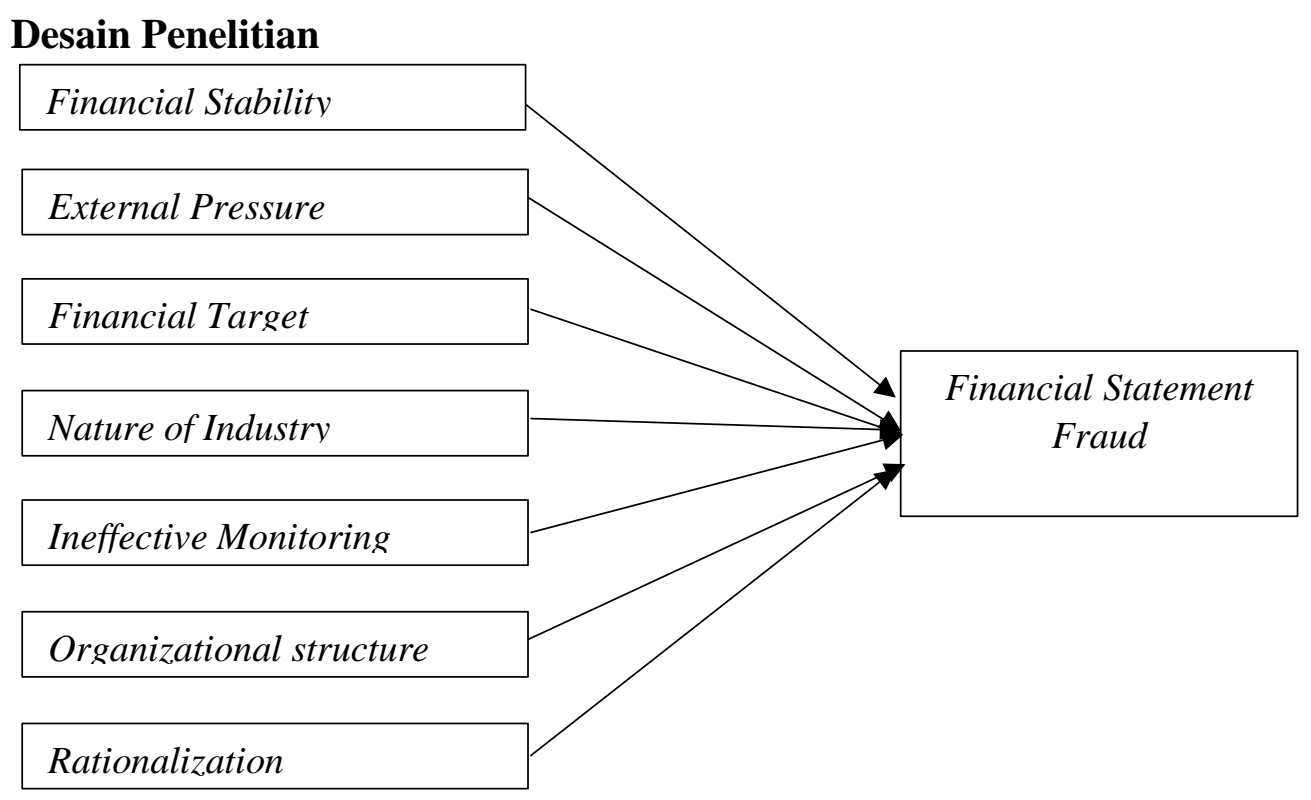

Hipotesis Penelitian

a. Financial Stability

Memproksikan financial stability dengan melihat perubahan total asset. Perubahan total asset mengalami kecenderungan menurun dapat menjadi pemicu kecurangan disebabkan total asset menjadi salah satu focus dari investor untuk berinvestasi. Menurut hasil penelitian Mulford (2010) dalam Wahyuni dan Budiwitjaksono (2017), presentase perubahan total aset dapat diduga terjadi manipulasi laporan keuangan, disebabkan tingginya presentase perubahan total aset guna memperlihatkan earning power perusahaan dan lebih kuatnya posisi financial.

\section{b. External Pressure}

Menggunakan utang dalam operasional dapat dikatakan meguntungkan jika perusahaan mampu menghasilkan laba. Namun leverage tinggi akan berisiko gagal bayar, saat ada penurunan profibilitas. Leverage yang tinggi dapat memberikan tekanan kepada manajer. Manajer dituntut untuk memberikan kinerja yang sesuai dengan harapan investor dengan memanfaatkan sumber modal yang dihasilkan melalui hutang, Leverage sebagai proksi eksternal pressure, leverage perusahaan tinggi maka semakin tinggi juga kemungkinan manipulasi laporan keuangan terjadi untuk mendapatkan tambahan modal dalam menjalankan kegiatan operasi pada perusahaannya.

\section{c. Financial Targets}

Return On Asset (ROA) banyak digunakan untuk menunjukkan bagaimana efisiennnya dipergunakannya aset untuk memperoleh laba. ROA dapat digunakan mengukur seberapa besar kinerja perusahaan. Melihat besarnya peran ROA sebagai media daya tarik investor maka sering terjadi indikasi kecurangan laporan keuangan melalui pencapaian target dari ROA.

\section{d. Nature of Industry}

Laporan keuangan yang terindikasi kecurangan dapat terlihat dengan mengamati nature of Industry dengan menggunakan proksi besarnya transaksi perusahaan dengan pihak yang mempunyai hubungan istimewa. 


\section{e. Ineffective Monitoring}

Pengawasan yang baik dapat mengawasi manajemen dalam mengelola perusahaan untuk mencapai strategi bisnis, pengawasan dapat mengurangi praktik kecurangan laporan keuangan. Dewan komisaris sebagai pengawas yang efektif dalam perusahaan, maka dari itu jumlah dewan komisaris independen sangatlah berpengaruh untuk perusahaan agar perusahaan tidak melakukan fraud. Semakin banyak dewan komisaris independent dalam perusahaan diduga dapat mengurangi fraud. Hasil penelitian Gunarsih dan Hartadi (2002) dalam Wahyuni dan Budiwitjaksono (2017) bahwa dewan komisaris dapat memberikan pengawasan ke manajemen tingkat atas.

\section{f. Organizational Structure}

Organizational Structure, menggunakan proksi pergantian direksi, Pergantian dewan direksi terjadi karena beberapa hal seperti yang diungkapkan pada peraturan OJK pasal 33 tahun 2014. Pergantian dewan direksi bukan berarti adanya kecurangan. Pergantian dapat bertujuan untuk memberikan kinerja perusahaan lebih baik dari periode sebelumnya. Bergantinya dewan direksi diharapkan memperbaiki kinerja direksi sebelumnya sehingga menurun indikasi kemungkinan terjadinya kecurangan.

\section{g. Rationalization}

Sorenson et al., (1983) mengurangi kemungkinan terjadi kcurangan dengan melakukan penggantian auditor

Penelitian Shu (2000) dan Krishnan (2005) menyimpulkan auditor yang mengundurkan diri mempunyai pengaruh yang positif terhadap kemungkinan terjadinya kecurangan.

\section{METODE PENELITIAN}

\section{Variabel bebas (Independent Variable)}

Penelitian ini menggunakan variabel bebas sebagai berikut :

1. Financial Stability di proksikan dengan perubahan aset

2. External Pressure di proksikan dengan leverage

3. Financial Targets di proksikan dengan Return Of Assets

4. Nature Of Industry di proksikan dengan transaksi pihak istimewa

5. Ineffective Monitoring di proksikan dengan proporsi jumlah dewan komisaris independen (BDOUT)

6. Organizational Structure menggunakan proksi jumlah direksi yang meninggalkan perusahaan selama satu tahun .

7. Rationalization menggunakan pergantian Kantor Akuntan Publik

\section{Jenis Data}

Data dokumenter merupakan jenis data penelitian ini, sedangkan data sekunder merupakan sumber data penelitian.

\section{ANALISIS HASIL DAN PEMBAHASAN}

\section{Seleksi Pemilihan Sampel Penelitian}

Sampel berjumlah 88 laporan keuangan yang diperoleh dari penyaringan populasi dengan kriteria. 


\section{Analisis Statistik Deskriptif}

\begin{tabular}{|rl|r|r|r|r|}
\hline \multicolumn{7}{|c|}{ Dchange } \\
& Frequency & Percent & Valid Percent & $\begin{array}{c}\text { Cumulative } \\
\text { Percent }\end{array}$ \\
\hline Valid & 0 & 51 & 58,0 & 58,0 & 58,0 \\
& Ada pergantian direksi & 37 & 42,0 & 42,0 & 100,0 \\
& Total & 88 & 100,0 & 100,0 & \\
\hline
\end{tabular}

Sumber: Data diolah

AudChange

\begin{tabular}{|ll|r|r|r|r|}
\hline & & & & Cumulative \\
& Frequency & Percent & Valid Percent & Percent \\
\hline Valid & Tidak ada pergantian auditor & 82 & 93,2 & 93,2 & 93,2 \\
& Ada pergantian auditor & 6 & 6,8 & 6,8 & 100,0 \\
& Total & 88 & 100,0 & 100,0 & \\
\hline
\end{tabular}

Sumber: Data diolah

\section{Classification Table ${ }^{a}$}

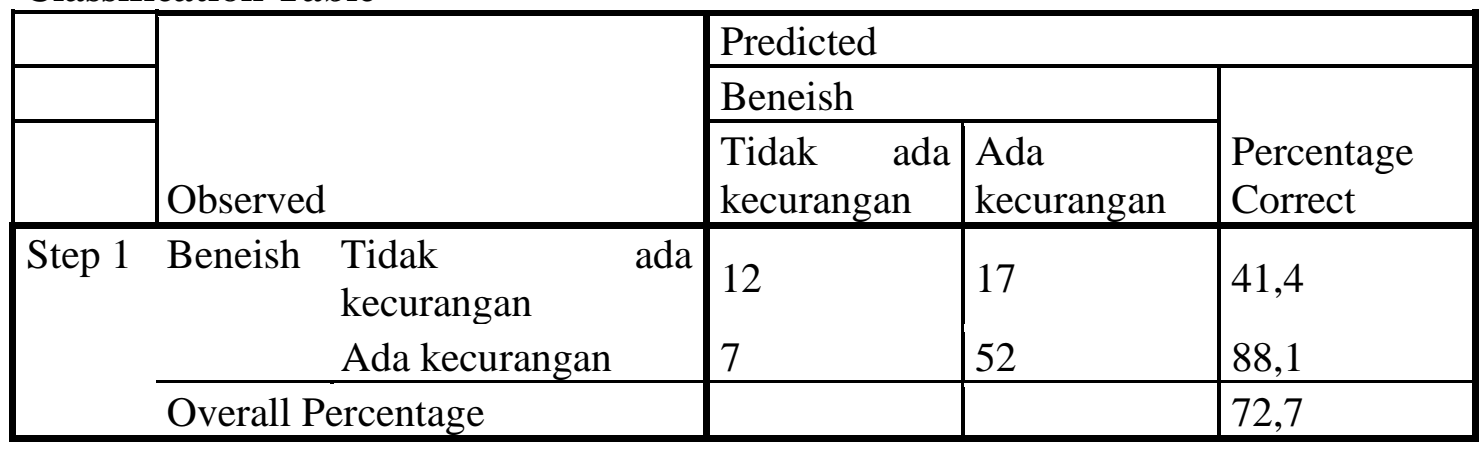

\section{Sumber: Data diolah}

\begin{tabular}{|l|l|l|l|l|l|l|}
\hline & $\mathrm{N}$ & Range & Minimum & Maximum & \multicolumn{2}{|l|}{ Mean } \\
\cline { 2 - 7 } & Statistic & Statistic & Statistic & Statistic & Statistic & $\begin{array}{l}\text { Std. } \\
\text { Error }\end{array}$ \\
\hline Achange & 88 & 1,91 & $-1,01$ &, 90 &, 0780 &, 01991 \\
Leverage & 88 & 1,11 &, 00 & 1,11 &, 3558 &, 02029 \\
ROA & 88 &, 74 &, 00 &, 74 &, 0839 &, 00973 \\
RPT & 88 &, 13 &, 06 &, 07 &, 0028 &, 00251 \\
BDOUT & 88 &, 40 &, 20 &, 60 &, 3902 &, 00866 \\
Valid N & 88 & & & & & \\
(listwise) & & & & & & \\
\hline
\end{tabular}

Tabel diatas memberikan gambaran bahwa nilai minimum Achange bertanda negative artinya ada perusahaan yang mempunyai nilai total asset tahun sekarang lebih kecil dari tahun lalu, namun rata-rata perubahan total asset bertanda positif yang menunjukkan bahwa rata-rata perusahaan masih banyak mempunyai total asset tahun sekarang dibandingkan tahun yang lalu. Variabel leverage, ROA, RPT, BDOUT 
bertanda positif yang menunjukkan perusahaan manufaktur dalam kondisi baik. Pergantian eksekutif dan pergantian auditor mempunyai nilai rata-rata dibawah $50 \%$ artinya pergantian eksekutif dan pergantian auditor tidak sering mengalami perubahan. Variabel Kecurangan laporan keuangn yang diukur dengan metode beneish menunjukkan nilai $0,67 \%$ artinya lebih dari $50 \%$ perusahaan manufaktur mengalami kecurangan.

Pergantian Direksi sebesar 58\%. Tidak ada pergantian auditor 93,2 \%. Perusahaan yang mengalami kecuranga laporan keuangan sebanyak 88,1\% (52 perusahaan) dan tidak mengalami kecurangan sebanyak 41,4\% ( 29 perusahaan).

\section{Analisis Regresi Logistik}

\section{Menilai Keseluruhan Model Fit (Overall Model Fit)}

Iteration History $\mathbf{y}^{\mathrm{a}, \mathrm{b}, \mathrm{c}, \mathrm{d}}$

\begin{tabular}{|c|c|c|c|c|c|c|c|c|c|}
\hline \multirow[b]{2}{*}{ Iteration } & \multirow[b]{2}{*}{$\begin{array}{l}-2 \quad \text { Log } \\
\text { likelihood }\end{array}$} & \multicolumn{8}{|c|}{ Coefficients } \\
\hline & & Constant & Achange & Leverage & ROA & RPT & BDOUT & $\begin{array}{l}\text { EksCh } \\
\text { ange }\end{array}$ & $\begin{array}{l}\text { AudC } \\
\text { hange }\end{array}$ \\
\hline St 1 & 93,919 &, 178 & 2,221 &, 592 & $-1,112$ & 26,116 &, 356 &, 125 &,- 773 \\
\hline e 2 & 92,276 &, 349 & 2,966 & ,812 & $-1,500$ & 35,790 &,- 073 & ,249 &,- 781 \\
\hline $\mathrm{p} \quad 3$ & 92,232 &, 380 & 3,117 & ,886 & $-1,621$ & 37,578 &,- 165 & ,271 &,- 783 \\
\hline 4 & 92,232 &, 380 & 3,123 & 890 & $-1,627$ & 37,632 &,- 168 & ,271 &,- 783 \\
\hline 5 & 92,232 &, 380 & 3,123 & 890 & $-1,627$ & 37,632 &,- 168 & ,271 &,- 783 \\
\hline
\end{tabular}

Initial -2 Log Likelihood: 111,559

\section{Model Summary}

\begin{tabular}{|l|l|l|l|}
\hline Step & $\begin{array}{l}-2 \quad \text { Log } \\
\text { likelihood }\end{array}$ & $\begin{array}{l}\text { Cox \& Snell } \\
\text { R Square }\end{array}$ & $\begin{array}{l}\text { Nagelkerke R } \\
\text { Square }\end{array}$ \\
\hline 1 & $92,232^{\mathrm{a}}$ &, 197 &, 274 \\
\hline
\end{tabular}

Nilai -2Log Likelihood awal (Tabel Iteration History0) bernilai sebesar 111,559 dan nilai -2Log Likelihood akhir pada tabel 4.4 (Tabel Iteration History 1) bernilai 92,23. Berdasarkan hasil (output) tersebut memperlihatkan penurunan nilai -2Log Likelihood artinya model yang dihipotesiskan fit dengan data.

\section{Uji Kelayakan Model Regresi} Model Regresi Logistik

Hosmer and Lemeshow Test
\begin{tabular}{|l|l|l|l|}
\hline Step & Chi-square & Df & Sig. \\
\hline 1 & 10,258 & 8 &, 247 \\
\hline
\end{tabular}

Sumber: Data yang diolah 
Berdasarkan tabel Hosmer and Lameshow's of Test tersebut, dapat dilihat bahwa hasil nilai dari pengujian Hosmer and Lameshow's of Test adalah sebesar 10,258 dengan nilai probabilitas yang dimilikinya sebesar 0,247>0,05. Artinya model dapat memberikan prediksi nilai observasinya.

Koefisien Determinasi (Nagelkerke R Square)

Uji Koefisien Determinasi

Model Summary

\begin{tabular}{|l|l|l|l|}
\hline Step & $\begin{array}{l}-2 \quad \text { Log } \\
\text { likelihood }\end{array}$ & $\begin{array}{l}\text { Cox \& Snell } \\
\text { R Square }\end{array}$ & $\begin{array}{l}\text { Nagelkerke R } \\
\text { Square }\end{array}$ \\
\hline 1 & $92,232^{\mathrm{a}}$ &, 197 &, 274 \\
\hline
\end{tabular}

Terlihat pada table nilai Nagelkerke $R$ Square yaitu 0,274 variabel dependen sebesar 27,4 \% mampu dijelaskan oleh variable independent dan selebihnya 72,6 \% dipengaruhi variable yang lain.

Uji Signifikansi Model Secara Simultan (Uji Omnibus)

Omnibus Tests of Model Coefficients

\begin{tabular}{|ll|l|l|l|}
\hline & & Chi-square & Df & Sig. \\
\hline Step 1 & Step & 19,326 & 7 &, 007 \\
& Block & 19,326 & 7 &, 007 \\
& Model & 19,326 & 7 &, 007 \\
\hline
\end{tabular}

Nilai signifikan sebesar $0,007<0,05$ artinya variabel independen dapat berpengaruh simultan terhadap variabel dependen.

\section{Koefisien Regresi}

Variables in the Equation

\begin{tabular}{|c|c|c|c|c|c|c|c|c|c|}
\hline & \multirow[b]{2}{*}{ B } & \multirow[b]{2}{*}{ S.E. } & \multirow[b]{2}{*}{ Wald } & \multirow[b]{2}{*}{ Df } & \multirow[b]{2}{*}{ Sig. } & \multirow[b]{2}{*}{$\operatorname{Exp}(B)$} & \multicolumn{2}{|c|}{ 95\% C.I.for EXP(B) } \\
\hline & & & & & & & & Lower & Upper \\
\hline \multirow{9}{*}{$\begin{array}{l}\text { Step } \\
1^{\mathrm{a}}\end{array}$} & Achange & 3,123 & 1,792 & 3,036 & 1 & ,081 & 22,707 & 677 & 761,683 \\
\hline & Leverage &, 890 & 1,625 &, 300 & 1 & ,584 & 2,435 & , 101 & 58,900 \\
\hline & ROA & $-1,627$ & 3,539 & ,211 & 1 & ,646 & , 197 & ,000 & 202,119 \\
\hline & RPT & & & & & & 2205829 & & 76125827 \\
\hline & & 37,632 & 13,555 & 7,708 & 1 & ,005 & $\begin{array}{l}5879322 \\
656,000\end{array}$ & 63916,339 & $\begin{array}{l}59104184 \\
00000000 \\
0000,000\end{array}$ \\
\hline & BDOUT &,- 168 & 3,415 & ,002 & 1 & ,961 &, 845 & ,001 & 681,461 \\
\hline & $\begin{array}{l}\text { EksChang } \\
\text { e }\end{array}$ &, 271 & ,556 & ,237 & 1 & ,626 & 1,311 & ,441 & 3,903 \\
\hline & $\begin{array}{l}\text { AudChan } \\
\text { ge }\end{array}$ &,- 783 & ,967 & ,656 & 1 & ,418 & ,457 & ,069 & 3,043 \\
\hline & Constant & ,380 & 1,387 & 075 & 1 & ,784 & 1,463 & & \\
\hline
\end{tabular}

Jurnal Ilmiah Akuntansi dan Ekonomi Volume. 6 Nomor. 2, Agustus 2021 Hal. 23 
Tabel diatas menunjukkan dengan tingkat signifikansi $(\alpha) 5 \%$, persamaan regresi dari uji regresi logistic yaitu:

\section{Fraud $=$ 0,380 + 3,123 AChange + 0,890 Leverage -1.627 ROA + 37,632 RPT - 0,168 BDOUT + 0,271 Ekschange - 0,783 AudChange}

\section{Interpretasi Hasil}

\section{Financial Stability Tidak berpengaruh Terhadap Kecurangan Laporan} Keuangan

Total asset yang mengalami penurunan membuat investor tidak melirik untuk berinvestasi mengingat asset merupakan salah satu focus investor sebelum memutuskan untuk berinvestasi. Sesuai dengan yang dikemukan oleh Wahyuni dan Budiwitjaksono (2017), perubahan aset dapat menunjukkan earning power dari suatu perusahaan. Total asset tidak akan mempengaruhi investor dalam berinvestasi sehingga besar kecilnya perubahan total asset tidak akan berdampak menimbulkan tindakan memanipulasi keuangan.

Hasil penelitian tidak sejalan dengan Tiffani dan Marfuah (2015) dan Skousen et al. (2009). Namun sejalan dengan Zaki (2017), Rachmania (2017), Aprilia dan Cicila (2015) yang menjelaskan perubahan aset tidak berpengaruh terhadap financial statement fraud

\section{External Pressure Tidak berpengaruh Terhadap Kecurangan Laporan Keuangan}

Skousen et al. (2009) dan Zaki (2009) menjelaskan leverage berpengaruh positif terhadap financial statement fraud. Hal tersebut tidak sesuai dengan hasil penelitian ini, namun sesuai dengan penelitian yang dilakukan oleh Nurrizkiana dan Shafira (2017), external pressure tidak berpengaruh terhadap financial statement fraud.

Financial Target Tidak Berpengaruh Terhadap Kecurangan Laporan Keuangan

ROA sebagai salah satu factor fundamental perusahaan menjadi perhatian investor untuk melihat kinerja perusahaan sebelum mereka berinvestasi, ROA yang tinggi di tahun ini menjadi tuntutan bagi manejemen untuk mencapai laba yang tinggi pula di tahun berikutnya dari sumber daya asset yang ada. ROA dapat dijadikan pertimbangan perusahaan untuk memberikan besar kecilnya bonus atau insentif untuk para direksi. Sesuai dengan teori agency dimana pihak principal menginginkan manajemen menghasilkan laba seting-tingginya, tuntutan-tuntutan tersebut membuat tekanan kepada pihak manajemen untuk melakukan mempercantik laporan keuangannya. Pernyataan -pernyataan diatas tidak didukung dengan hasil penelitian ini karena financial target yang diproksikan dengan ROA tidak memberikan pengaruh terhadap kecurangan laporan keuangan. ROA tidak menimbulkan tekanan kepada pihak manajemen dalam melakukan kecurangan. Kemungkinan kecurangan dapat timbul dari luar factor fundamental perusahaan mengingat perusahaan-perusahaan yang listing di bursa mendapat pengawasan ketat, sehingga kecil kemungkinan perusahaan melakukan kecurangan di bagian fundamental perusahaan. 


\section{Nature of Industry Berpengaruh Terhadap Kecurangan Laporan Keuangan}

Nature of industry diproksikan dengan keterlibatan pihak istimewa dalam perusahaan. Hasil penelitian ini menunjukkan bahwa transaksi pihak istimewa dapat mempengaruhi kecurangan laporan keuangan. Hubungan istimewa yang kompleks dapat memiliki risiko pada laporan keuangan karena salah saji yang material yang besar. Young (2005) memberi penjelasan, transaksi yang dilakukan dengan pihak istimewa diduga memiliki hubungan istimewa dapat mendorong manajemen melakukan manipulasi laba, melakukan kecurangan dan penjarahan perusahaan. Hubungan istimewa dapat terjadi antara induk perusahaan dan anak perusahaan. Kedua pihak tersebut sangat memiliki ketergantungan, induk perusahaan manufaktur akan membeli ke anak perusahaan untuk kebutuhan bahan baku maka disinilah timbul piutang hubungan istimewa. Akibat piutang hubungan istimewa ini bisa terjadi kecurangan karena piutang dan persediaan merupakan objek yang dapat mudah dimanipulasi sesuai dengan penelitian Summers dan Sweeney (1998) mencatat estimasi dari akun yang tidak dapat ditagih dan persediaan ditentukan secara subyektif. Ineffective monitoring tidak berpengaruh terhadap kecurangan laporan keuangan (H5) ditolak.

Keberadaan dewan komisaris independen sangat penting dalam perusahaan sebagai pengawas. Pengawasan bertujuan untuk mengelola perusahaan sesuai dengan tujuan. Hasil uji data menunjukkan ineffective monitoring tidak berpengaruh terhadap kecurangan laporan keuangan. Membuktikan bahwa sesuai dengan peraturan OJK yang menjelaskan bahwa komisaris independent minimal 30\% dari seluruh dewan komisaris tidak dapat memberikan pengawasan. Besar kecilnya jumlah dewan komisaris independent tidak memberikan pengaruh terhadap terjadinya kecurangan.. Walaupun dalam melakukan pengawasan dewan komisaris independent tidak mendapat pressure dari principal dan manajemen tetap tidak dapat memberikan pengaruh dalam terjadinya praktek kecurangan. Komisaris independen dalam melakukan pengawasan terbatas dengan adanya peraturan dari para pemegang saham.

Skousen et al. (2009) menunjukkan bahwa ineffective monitoring mempunyai pengaruh negatif terhadap financial statement fraud. Sedangkan penelitian yang dilakukan oleh Rachmania (2017), Iqbal dan Murtanto (2016) dan Zaki (2017) mendapatkan hasil yang berbeda yaitu ineffective monitoring tidak berpengaruh terhadap financial statement fraud.

\section{Organizational Structure Tidak Berpengaruh Terhadap Kecurangan Laporan Keuangan}

Data frequency menunjukkan bahwa jumlah sample yang tidak mengalami pergantian direksi (37) jumlahnya lebih kecil dari yang mengalami pergantian direksi (51). Pergantian dewan direksi beberapa diantaranya dapat disebabkan karena habis masa jabatan direksi lama ( masa jabatan 5 tahun). Adanya Pergantian direksi diharapkan dapat memberikan perbaikan kinerja perusahaan. Penggantian direksi lama mempunyai kompeten yang tinggi sehingga mampu memberikan pengawasan kepada perusahaan dengan kebijakan-kebijakan barunya yang dapat menghasilkan profitabilatas yang tinggi. Hasil penelitian ini membuktikan bahwa pergantian dewan 
direksi tidak mempengaruhi terjadi kecurangan laporan keuangan. Dugaan bahwa adanya pergantian direksi berpengaruh negative terhadap kecurangan tidak terbukti. Artinya bahwa pergantian direksi hanya untuk menaati peraturran OJK bahwa direksi maksimal 5 tahun harus dilakukan pergantian direksi.

\section{Rationalization Tidak Berpengaruh Terhadap Kecurangan Laporan Keuangan}

Pergantian auditor tidak berpengaruh dengan terjadinya kecurangan. Perusahaan membuat kebijakan pergantian auditor karena pasal 3 ayat 1 Peraturan Menteri Keuangan Republik Indonesia Nomor 17/PMK01/2008 yang mengatur berapa lama pergantian auditor dan KAP

\section{KESIMPULAN DAN SARAN Kesimpulan}

Secara partial masing-masing variable berikut yaitu Financial stability, Organizational, External pressure. financial target, , Ineffective monitoring, dan Rationalization tidak berpengaruh terhadap kecurangan laporan keuangan. Nature of Industry berpengaruh terhadap kecurangan laporan keuangan.

\section{Saran}

1. Penelitian selanjutnya bisa memperluas tahun penelitian dan menambah jumlah perusahaan sebagai populasi penelitian

2. Disarankan untuk menambahkan variabel independen yang lain untuk melihat kecurangan laporan keuangan missal variabel manajemen laba. 


\section{DAFTAR PUSTAKA}

ACFE, 2016. Report To The Nation On Occupational Fraud And Abuse 2018 Global Fraud Study, Association Of Certified Fraud Examiner

Accounting Standard Board (ASB). 2002. Statement on Auditing Standard (SAS) No. 99. Consideration of Fraud in a Financial Statement Audit

C.J. Skousen, K. S. (2009). Detecting and Predicting Financial Statement Fraud : The Effectivenes Fraud Triangle and SAS No. 99. Journal of Corporate Governance and Firm Performance, 13, 53-81.

D.R.Cressey. (1953). Other people's Money dalam : "Detecting and Predicting Financial Statement Fraud : The Effectivenes of The Fraud Triangle and SAS No. 99", Skousen et al. 2009. Journal of Corporate Governance and Firm Performance 13, 53-81.

Harahap, Sofyan Syafri 2010. Analisa Kritis atas Laporan Keuangan. Cet 11. Jakarta: PT RajaGrafindo Persada.

Nurrizkiana, Shafira. 2017. Analisis Fraud Triangle Dalam Mendeteksi Financia Statement Fraud. Universitas Pendidikan Indonesia

Olson, V. (2017, November 15). Evolusi Fraud Triangle. Retrieved Juni 14, 2020, from rswastika: rswatika.blogspot.com

Rachmania, A. 2017. Analisis Pengaruh Fraud Triangle Terhadap Kecurangan Laporan Keuangan Pada Perusahaan Makanan Dan Minuman Yang Terdaftar Di Bursa Efek Indonesia Periode 2013-2015.

Tuanakotta, Theodorus, M. 2013. Audit Berbasis ISA (international Standard on Auditing). Jakarta: Salemba Empat.

Uzun,et al. 2004. Board Composition and Corporate Fraud. Financial Analysis Journal (May/Jun): 33-43.

Widiarti. (2015). Pengaruh Fraud Triangle Terhadap Deteksi Kecurangan Laporan Keuangan pada perusahaan manufaktur yang terdaftar di bursa efek Indonesia. Jurnal Manajemen dan Bisnis Sriwijaya, 12 (2). 